\title{
The Crisis in Russian Agriculture: A Comment
}

Not long ago Randolph Starn observed that the word "crisis" is a particularly ambiguous term which historians have not always used with the requisite care. "One historian's crisis lasts moments, another's decades, even eras; political, social, economic, mental, or moral crises are blurred by one historian's insistence on treating them discretely, while another lumps them together under the confusing rubric 'general crisis." "1 Starn's strictures about the abuse of common terminology and about the confusion resulting from such abuse deserve our attention, especially now that Professor James Y. Simms has asserted that Russian historians have been wrong in thinking that there was an agrarian crisis in the late nineteenth century. ${ }^{2}$ It is to Simms's credit that he has criticized several dubious aspects of the crisis interpretation of fin de siecle agrarian history, and his criticisms may convince us that we should be more circumspect in employing the term "agrarian crisis" as a general description of the condition of the late nineteenth-century rural economy. Yet if Simms's observations underscore several weaknesses of the old interpretation and warrant greater caution and precision in our analysis of the agrarian crisis, they need not compel us to stop referring to the existence of the crisis-at least not yet. As Starn has suggested in the conclusion of his article, it is not essential that historians stop propounding crisis interpretations, but it is important that they "should be knowing and careful when using them."3

Simms's rejection of the crisis theory is based on a single perception: historians have argued incorrectly that the plight of the Russian peasantry as a whole grew worse in the late nineteenth century. By demonstrating that peasant purchases of consumer goods were increasing at the turn of the century, Simms claims to have undermined the notion that the standard of living was falling, and to have demolished the contention that the central government's taxation rates were prohibitively high for the peasantry. Thus, Simms believes that by a single stroke he has confuted not only the historians who have spoken so naively about the agrarian crisis, but also the many critics of Minister of Finance Witte's industrialization policy. Although I am prepared to admit that Simms's analysis is interesting and some of his evidence intriguing, I do think that much of his evidence is shaky and that his revisionism is premature.

The first major problem with Simms's argument is that it does not pay sufficient attention to the way in which other scholars and contemporary ob-

1. Randolph Starn, "Historians and 'Crisis," Past and Present, 52 (August 1971): 3.

2. See Simms's article, "The Crisis in Russian Agriculture at the End of the Nineteenth Century: A Different View," Slavic Review, 36, no. 3 (September 1977) : 377-98.

3. Starn, "Historians and 'Crisis," " pp. 21-22. 
servers have used the term "agrarian crisis." It should be understood at the outset that the Russian word "krizis" is often employed in the same sense as the English word "depression." Thus, when Soviet scholars speak of an "agrarnyi krizis" in the late nineteenth century, they frequently refer merely to the agricultural price depression of 1883-96. Lenin, P. L. Liashchenko, N. A. Egiazarova, and others occasionally wrote about the existence of an agrarian crisis in this narrow sense. It is true that the expression "agrarnyi krizis" has acquired other connotations, and can refer broadly to the psychological, social, and economic consequences of a price depression or of another type of economic dysfunction. However, any critic of the "crisis theory" ought to distinguish between denotative and connotative meanings of the term. To fail in this responsibility risks spreading confusion where one ought to be promoting clarity. Simms also ignores another use of the term "agrarian crisis" common in nineteenth-century documents. Noble landowners spoke about the net decline in the land fund owned by the dvorianstvo, and about the nobility's increasing resort to bank loans and estate mortgages as evidence of an agrarian crisis. ${ }^{4}$ Spokesmen for the landed elite had various theories about the origins of this crisis. Some believed that it started when the emancipation forced the conversion from serfdom and natural economy to free labor and a monetary economy; others thought that the agrarian crisis began with the fall of cereal prices in the $1880 \mathrm{~s}$. Whatever one thinks of these propositions, it is clear that in late nineteenth-century Russia discussions about the agrarian crisis did not deal exclusively, or even generally, with the peasant question. If the existence of an agrarian crisis is above all a matter of definition and perspective, then Simms can be faulted for not reviewing systematically the ways his predecessors have seen and defined the crisis.

Second, Simms's argument fails to acknowledge important nuances in previous treatments of the agrarian crisis. It is certainly commendable to chide those historians who have written in sweeping terms about "the exhaustion of the paying powers of the population, or the universal poverty of the peasantry." Yet it is both inaccurate and unfair to imply, as I think Simms does, that other scholars have made their interpretations of the agrarian crisis depend on an assumption of universal rural impoverishment. ${ }^{5}$ In fact, from the very beginning, government experts and Russian intellectuals showed a keen awareness of the variations of wealth within single peasant communities and of different living standards prevailing in the separate regions of the Russian Empire. One of the earliest government investigations of the agrarian crisis that has come to my attention was the report by the so-called Plehve Commission in 1892. This report noted explicitly that the price depression of the 1880 s affected commercial grain producers in the eastern and central areas of the black soil zone more severely than it harmed producers in the industrial north or in the wheat-

4. For examples of gentry concern about the "agrarian crisis" facing the nobility, see Tsentral'nyi gosudarstvennyi istoricheskii arkhiv Leningrada (TsGIAL), fond 593 (Gosudarstvennyi dvorianskii zemel'nyi bank), opis' 1 , delo 47, listy 330 and 507; see also Trudy Vserossiiskogo s'ezda sel'skikh khoziaev, vol. 5: Doklad B. V. Lilienfel'da (Moscow, 1896), p. 10.

5. "The implication is clear: it was the mass of the population, or the vast majority of the peasants, who had become impoverished and destitute by the turn of the century. This is a basic component in the crisis hypothesis" (Simms, "The Crisis in Russian Agriculture," p. 378). 
growing southwestern provinces. ${ }^{6}$ After the famine of 1891-92 discussions on the agrarian crisis concentrated on the plight of the peasantry in the Central Agricultural and Volga provinces, where the famine struck hardest. ${ }^{7}$ Modern scholars have not forgotten that agricultural problems were more severe, and the condition of the peasants generally worse, in particular provinces or regions of the empire. ${ }^{8}$

It is not necessary to describe the state of historiography on the social stratification of peasant communities. Suffice it to say that since the publication of Lenin's Development of Capitalism in Russia most serious scholars have acknowledged that there was at least some differentiation of wealth in the Russian village. The debate has been about the degree and permanence of this differentiation, and about its causes and consequences. Lenin himself made the existence of various peasant strata both an integral part of his treatment of the agrarian crisis and an important element of his political strategy. In light of these well-known facts, it is surprising that Simms would try so hard to convince us that all adherents of the crisis theory deal with the peasantry as a whole, and it is ironic, rather than paradoxical, that Simms should find Lenin a supporter of the view that peasant standards of living were generally improving. What mattered to Lenin and so many other scholars was not how the peasantry fared en masse in government reports, but rather how the millions of peasants in the poorer strata and in the poorer regions of the country fared in reality. When Simms finally confronts Lenin's central argument ("they [the rural proletariat] become poorer, but at the same time receive and spend more money -and both these sides of the process are necessary for capitalism"), he is forced to admit that "the data necessary for resolving the problem posed by Lenin apparently do not exist." 9 The fate of the poor peasantry is the crux of the agrarian crisis interpretation, yet it is here that Simms's evidence is weakest.

6. Doklad predsedatelia vysochaishe uchrezhdennoi $v 1888$ godu kommissii po povodu padeniia tsen na sel'skokhoziaistvennye proizvedeniia v piatiletie 1883-1887 (St. Petersburg, 1892), pp. 61-66.

7. One government commission which dealt with the peasant problem in the wake of the famine was the so-called "Commission on the Center" (see Issledovanie ekonomicheskogo polozheniia tsentral'no-chernozemnykh gubernii: Trudy osobogo soveshchaniia 1899-1901 gg. [Moscow, 1901]).

8. See, for example, M. S. Simonova, "Problema 'oskudeniia' tsentra i ee rol' v formirovanii agrarnoi politiki samoderzhaviia v 90-kh godakh XIX-nachale XX v.," in Problemy sotsial'no-ekonomicheskoi istorii Rossii: Sbornik statei (Moscow, 1971), pp. 236-63.

9. Simms, "The Crisis in Russian Agriculture," p. 396. Simms follows this admission by arguing that wages for agricultural laborers rose faster than rye prices in the 1890 s, and by repeating his earlier point on the rise of consumption. It is fascinating to note that Simms's data on wages, taken from Geroid T. Robinson's well-known chapter, "The Hungry Village," are also taken out of context. I do not have the space to quote Robinson in full, but he notes that wages generally declined from 1882 until they began to go up again in the early 1890 s. Then from 1895 to 1901 wages rose in ten of thirteen regions of Russia. However, they fell rapidly after 1901, declining in twelve out of thirteen regions. Robinson concludes his paragraph by saying that for the poorest peasants, who were most dependent on wages, "the period which immediately preceded the Revolution of 1905 was one of more than usual distress." For Robinson's complete citation, the reader should see Geroid T. Robinson, Rural Russia under the Old Regime (Berkeley and Los Angeles: University of California Press, 1969), pp. 105-6. By quoting only those statistics that happen to be convenient for his case, Simms, it seems to me, violates his readers' trust and common scholarly practice. 
A third problem with Simms's thesis is connected with the evidence which he does cite. I do not think it too harsh to say that in his eagerness to demonstrate the shortcomings of the crisis theory, Simms is sometimes casual and superficial in his own use of documents. The hastiness and inaccuracy which probably account for small errors (for example, the sloppy translation of the minister of finance's budget report on page 393, and the incorrect identification of F. A. Shcherbina as a female professor on page 395) may also account for Simms's more serious blunders. In his discussion of per capita grain production in Russia, Simms writes: "The Soviet scholar A. S. Nifontov has also made calculations which agree with these findings: after subtracting exports there was more grain available per capita in Russia in 1900 than in the 1880s."10 Simms footnotes page 310 of Nifontov's recent book, Zernovoe proizvodstvo Rossii, but on page 310 of that book there is no calculation by Nifontov of grain available per capita after exports, nor is such a calculation to be found elsewhere in Nifontov's book. ${ }^{11}$ Perhaps Simms makes use of Nifontov's data on the amount of grain available for the economic needs of the population in his own separate calculation of per capita production, but no one can tell from Simms's footnote where Nifontov's work ends and Simms's opinion begins.

Simms is also cavalier in his analysis of Alexander Gerschenkron's argument on per capita production. Simms notes that Gerschenkron's production figures refer "only to wheat and rye, and do not take into consideration barley, oats, and corn, which were becoming more important in Russia."12 What Simms disregards is that oats were primarily used for animal feed, and seldom for human consumption. Corn was grown only in the south (especially in Podolia, Bessarabia, and Kherson), and even in 1900 it represented less than one-half of one percent of the total annual harvest of grains. ${ }^{13}$ Then Simms indicates that although Gerschenkron's “index for per capita output of wheat and rye was lower in 1896-1900 than in 1870-74, it shows a definite rise for the period 1886-90. It is possible to conclude from Gerschenkron's own evidence that the rural sector was experiencing a recovery and not a deepening crisis."14 This assertion is illogical, to say the least, unless Simms would have us study only pre-1890 figures.

Fourth, Simms's observations, even when grounded in fact, are sometimes not connected coherently with what we know about other features of nineteenthcentury development. Simms attempts to demonstrate that there was no agrarian crisis because peasants' real income from handicrafts, industrial wage labor,

10. Simms, "The Crisis in Russian Agriculture," p. 391.

11. Nifontov provides a chart which shows that the total amount of grain available for the economic needs of the populace ("na khoziaistvennye nuzhdy naseleniia") grew from 149,100 chetverti in the 1870 s to 203,700 chetverti in the 1890 s. Nifontov does not attempt to give per capita figures here, so one must assume that Simms made his own calculations, or else cited the wrong source. Nifontov does provide other tables in his book which give per capita grain production (tables 43 and 44, pp. 284-89), but these tables are based on the net harvest and do not subtract the amount of grain exported (see A. S. Nifontov, Zernovoe proizvodstvo Rossii vo vtoroi polovine XIX veka po materialam ezhegodnoi statistiki urozhaev evropeiskoi Rossii [Moscow, 1974]).

12. Simms, "The Crisis in Russian Agriculture," p. 391.

13. On oats production and use see Nifontov, Zernovoe proizvodstvo Rossii, pp. 255-59; on corn, see ibid., pp. 264-65, 270.

14. Simms, "The Crisis in Russian Agriculture," p. 391. 
and day labor on farms increased in the late nineteenth century. The trouble is that Simms's explanation reverses the clear connection between agricultural poverty and the eventual exit from the communes by many peasants. Other historians have argued that the peasants, facing at best a cloudy future in agriculture, were driven by the agrarian depression to seek supplementary income from handicrafts, day labor, and industrial work. ${ }^{15}$ Ultimately, the agrarian crisis forced a huge number of peasants to give up agriculture altogether for jobs in the cities. If conditions in rural Russia had been improving generally in the manner that Simms argues they did, then the formation of a sizable urban working class might have been delayed for decades.

It is much easier, of course, to criticize Simms's questionable assertions than it is to assemble one's own logical description of late nineteenth-century social and economic history. However, I should think that even with the evidence currently at our disposal certain features of rural Russia can be noted. The central fact of the period was the demographic revolution that threatened to overrun land resources and to outstrip food production. By 1897 there were 129 million people in the Russian Empire, some five-sixths of whom were peasants. The impressive achievements of Russian agriculture after 1870greater harvests because of higher yields, the more extensive cultivation of dry lands in the south and of Siberian arable, and the widespread growing of potatoes-enabled the economy to support the population, but the balance between survival and starvation for the poorer peasants in certain regions of the country was precarious. In years like 1891-92, the delicate balance between food supply and population shifted, and the result was famine. Even in good years, many peasants did not have enough land to till and barely had enough to eat. For the peasants who were fortunate enough to produce surplus grain for the commercial market, as well as for the landed gentry, there were serious problems in adjusting to rural capitalism. During the Great Depression of 1883-96 production costs exceeded income from grain sales in many provinces for many years. Thus, even commercial producers were compelled to seek additional sources of capital to keep their farming operations going. Borrowing from the central government, from local banks, and from private individuals became a way of life for large numbers of "prosperous" peasants and gentry landowners. In addition, both poor and "wealthy" peasants tried to supplement their inadequate incomes through handicrafts or jobs in the cities. One must not conclude from the tenuous evidence on increased consumption of essential goods (matches, kerosene, textiles) that it was income from agriculture alone which enabled peasants to purchase these consumer items. Finally, there were social tensions in late nineteenth-century Russia. Many peasants, beleaguered by the threat of starvation or upset by the fluctuations of the grain market, either could not or would not make their redemption payments; tax collectors faced increasing noncompliance. Moreover, peasant attitudes toward the gentry-always char-

15. On the dimensions of the peasant migration to St. Petersburg from the late 1860 s to 1914, see James H. Bater, St. Petersburg: Industrialization and Change (Montreal: McGillQueen's University Press, 1976), pp. 308-21. Bater offers no blanket explanation for the influx of peasants to Petersburg. He does propose that some were drawn by industry or the prospect of nonindustrial employment in Petersburg; he also implies that rural poverty influenced many" peasants: "The source of many peasant migrants was the impoverished and overpopulated non-black earth region of central Russia" (Bater, ibid., pp. 385-86). 
acterized by mistrust--seemed to harden at the turn of the century, especially in provinces like Poltava and Kharkov where major peasant disturbances were to erupt in 1902. Meanwhile, the gentry, whose landed property was decreasing every year, felt threatened by the growing mass of peasants surrounding them. As gentry income from agriculture declined during the Great Depression, some conservative pomeshchiki turned to the government for subsidies and meliorative legislation. For others, the old system of legal and economic privileges lost its moral and historical sanction; these nobles became liberals out of idealism or fear of revolution. For certain conservative and liberal landowners, as for various groups of peasants, the agrarian crisis was not the invention of errant imaginations, as Professor Simms thinks. It was an economic, social, and psychological fact of life, as hard to escape as the grayness of the Russian winter. 